Reviews Studia Iuridica Lublinensia vol. XXVII, 4, 2018 DOI: 10.17951/sil.2018.27.4.165-170

Julia Pietrasiewicz

Jagiellonian University in Kraków

ORCiD: 0000-0001-7160-7692

julka.pietrasiewicz@gmail.com

\title{
Konstytucja USA. Ze studiów nad amerykańskim systemem politycznym (The United States Constitution. From the Studies of the American Political System), red. Michał Urbańczyk, Łukasz Bartosik, Marcin Tomczak, Poznań-Łódź 2018, pp. 289
}

The monograph Konstytucja USA. Ze studiów nad amerykańskim systemem politycznym (The United States Constitution. From the Studies of the American Political System) was published in 2018, what as is mentioned in the introduction part is not a coincidence. It is closely related to the fact that in 2017 Americans solemnly celebrated the $230^{\text {th }}$ anniversary of the enactment of their Constitution and 2019 is a year of the $230^{\text {th }}$ anniversary of the American basic law going into effect. The monograph is devoted to various issues related to the American Constitution. The work is divided into three parts. The first part considers selected issues of civil rights and their boundaries and consists of five articles, where authors are mainly bringing the subject of equality. The second part is devoted to the limits of state power and the detailed aspects of the functioning of the principle of separation of powers. The authors in their articles are explaining the complexities of the American system and the most important institutions implemented by the Constitution. The last part is the shortest one and is devoted to problems of the Supreme Court's jurisprudence. The last four articles are describing the most important problems and the issues associated with the case law of the Supreme Court, both at present and in the course of years.

Constitution of the United States of America is the fundamental law of the U.S. federal system of government and a landmark document of the Western world. It is still in use and since being established in 1787 was changed only 27 times. It 
influences system, politics, layout of forces in the country but it also has a significant influence on the forming has oneself of social relations. Authors mention in the introduction how unique and exceptional it is in comparison with other countries and they are also indicating these issues as main subjects in this monograph. Also in this part, we have a chance of superficial acquainting oneself with the plot of collected articles and we are obtaining information about authors. Editors are pointing that monograph was created by young researches for whom it is undoubtedly the beginning of a professional and academic career.

There is no doubt that this study can be qualified as a legal monograph, because it focuses on constitutional law, presents legal act as a set of fundamental principles and explains the influence of it on the country. It explains the changes that have taken place over the years and how this affects the current shape of the United States of America. Not once we can also find comparative elements, as the authors wanted to better explain their position evoke the systems of such countries as France, Germany and Poland. The extensive title is an unquestionable advantage because it allowed collecting articles that touch various aspects but at the same time create a still coherent whole. In my opinion, people with only a little knowledge of the American system can expand their knowledge in a very accessible way. At the same time, people familiar with this subject will surely find articles equally interesting and a valuable way to systematize knowledge. The system of monograph and the order of the issues do not raise any objections. There are logical and smoothly presented next issues raised in the most important legal act of the United States. The layout indicates that without a doubt social issues in the sense of editors are the most important element of the Constitution.

In the first part of the monograph, authors focused on civil rights. The topic of The influence of John Locke's private property theory on the Founding Fathers and the foundational documents of the American Republic is raised as a first. The author of this article is $Ł$. Bartosik. In this work firstly he tries to briefly cite the basics of Locke's philosophy and then the process of the adaptations of his theory of property by Founding Fathers. The author accurately and extensively presents elements of the work of "the father of liberalism". However, one may wonder whether the author should not have been more focused on the influence of the philosophy itself, in comparison to how much of the article is devoted to its explanation. Nevertheless, the author aptly pointed out the elements adopted by Founding Fathers. The second article written by I. Mędela, called Religious liberty in the contemporary jurisprudence of the Supreme Court of the United States of America based on the case Trinity Lutheran Church of Colombia, Inc. v. Comer, is a work about religious liberty and church in the United States. The author brings historical context and states that it is one of the most important issues since the beginning of the country. He proves his point by recalling two other cases that led to the title matter. He accurately and clearly indicates the elements that influenced the ruling. 
While citing the opinions of individual judges he marks that the issues referred to earlier in this article were of key importance, thanks to which the article became even more coherent. In my opinion, the author exhaustively answers the question in which direction the jurisprudence related to religious freedom will develop and notes that it is difficult to accept one position as it needs to be taken into account the fact that politics of the country is going to change after the election. Next article (The United States Constitution and the issue of slavery before the thirteenth amendment. Historical and legal considerations on an example of "black list" from the abolitionist newspaper "Genius of Universal Emancipation" by M. Tomczak) is an attempt to acquaint the problem of slavery in connection with the provisions of the Constitution and other legal acts. It was a very interesting solution to compare the purely theoretical situation with the real one - described in fragments of the "black list". Also the next article focuses on these issues and is a walkthrough legislation and U.S. jurisprudence shaping this position. M. Biskupski in the article The problematic aspects of slavery and equal rights against the racial background in the light of the American constitutionalism and the United States Supreme Court's judicature presented some important court decisions. In spite of short descriptions of events, the author managed to capture the most important elements thanks to which in a comprehensible and accessible way he recognized the principles, which influenced the shaping of politics. In my opinion, it is worth noting that the author devoted one of the parts for the evaluation, but personally I regret that he didn't present more of his own conclusions. The last article in this part is devoted to the topic, which always arouses unusually high interest - prohibition. Striving for the introduction of prohibition in the United States and its functioning and revocation is a paper by K. Świątczak. The author very cleverly divided his work into five parts, efficiently showing various issues regarding prohibition. The analysis covers both legal and social, economic and political issues and what is more important he manages to successfully confirm the thesis made at the beginning about the wrong decision of the American authorities concerning the introduction of prohibition.

The second part of the monograph concerns the limits of state power and the detailed aspects of the functioning of the principle of separation of powers. It consists of seven articles and introduces all three branches - legislative, executive and judiciary. First one, written by R. Wszołek, describes problem of the separation of powers and in the simple and understandable way presents the role of every power. I must admit that this is a very satisfactory opening to the next part and builds good grounds for understanding the American system. The author introduces every one of them without going into too many details, but it is definitely a solid base and more than enough to be able to understand the system and subsequent articles. In the article Association of deputies in the Polish and American parliament-comparative law study of the most important issues, B. Ślemp attempts to compare associations of deputies in the countries that are mentioned in the title. The author 
provides very detailed information about the Polish system, however, it seems that some information may have been omitted without prejudice to publication. In my opinion, there is a certain disproportion in presenting the organization of parliamentarians in Poland and America. Still, it must be admitted that he manages to emphasize the biggest differences. Third article Participation of President Trump in the legislative procedure by A. Suszek is an attempt to assess the influence of the president on the legislation. The author decided to use the example of the current president, what in fact made it easier to understand the mechanisms functioning in this system. What is more, to confirm his theses, he cites statistics, which clearly illustrates his words. He is not afraid of evaluating Trump's activity and pointing out his position, additionally, he's trying to put him in one of the categories created by J.D. Barber. Next article is more theoretical. $€$. Kielin in the study The role of the President of the United States in the process of adopting the federal budget examines the function of the president in the federal budgetary procedure. The aspects of the president's influence, both current and those that no longer exist, have been presented in an interesting way and it seems to me that the right conclusions have been drawn afterwards. It is also worth emphasizing that the author is not timid to determine his position and opinion on how the system should function. P. Stanek and J. Witt in the article The first years of the functioning of the United States Supreme Court as the period of its most intense formation present the issue of the formation of the U.S. Supreme Court institutions in the initial period of its existence. The authors aptly point to elements affecting the development of the court, highlighting how important the issue was for the politics over the last years. However, it can be concluded that the fragment about slavery could be omitted or shortened. It was supposed to emphasize the weaknesses of the Supreme Court, but at the same time is tarnishing the conclusions that have been drawn on its behalf. Autonomy of the 'States' and 'Lands' - a comparative analysis of federalism in the German and American Constitutions by A. Mawer and A. Ratajczak is another comparative paper. A comparison of the German and the American systems serves to describe different versions of federalism. The authors describe different points of view and ways of understanding this concept. It should be recognized that the way the federalism is presented turns out to be a very successful solution. Readers have a chance to easily captivate and understand the differences and the authors, thanks to that, can present their opinion and gave the possibility to start polemics. The last article in this part is called Enumerated powers clause in the United States Constitution as an example of the implementation of the principle of subsidiarity and is written by J. Jabłoński. It is undertaken on the principle of subsidiarity in the United States Constitution. The author scrupulously presents the content of The Federalist Papers, almost creating a summary. Then he cites judicial decisions and explains the limitation of the principle of subsidiarity, which was caused by adopting the Fourteenth Amendment. One can, however, consider whether this paper 
does not lack a more developed summary, it is in my opinion mainly a citation of contents of The Federalist Paper, without a deeper analysis or clear conclusions. However, it can be generally stated that this part of the monograph as a whole is also very successful. Individual topics have been presented in an interesting and insightful way, despite minor errors.

The last part is focusing on the problems of the Supreme Court's jurisprudence. The authors are introducing to the readers four concepts that are essential for understanding the functioning of the system. First work (Constitutional review. A comparative study between the American and the European systems) is written by A. Zwolankiewicz. She attempts to compare two control systems of the constitutionality of the law - the American and European model, also called 'Kelsenowski'. She accurately presents the elements of the American structures, describes them and then accurately indicates the differences with European structure. It is worth noticing that the author gives examples of functioning in several countries, thanks to that concept have become clearer. Next article is The case of originalism: An interpretative doctrine with a conservative background? by J. Nováková. She attempts to explain the originalism and its impact on judicial decisions and, consequently, the law. The definitive advantage is that when she is trying to summarize her considerations, she presented both the advantages and disadvantages of this approach. This is definitely a multifaceted doctrine that should not be judged unambiguously. The third article from this part is Textualism as a method of interpreting the constitution by M. Latacz and defines the concept of the theory of law interpretation. The author explains the theoretical aspect of interpretation in a very interesting and at the same time simple way. She quotes the words of the Constitution confirming the thesis of the article and then goes smoothly to explain the doctrine under different aspects. J. Konderla and A. Tarłowska are the authors of the article The impact of the Supreme Court's federal jurisprudence on the foreign policy of the United States of America. A reasonable solution, in this case, was to divide the article into four parts. In my opinion, they have pointed out the relevant court judgments both before 1989 and after and some good conclusions have been drawn from them. However, maybe it would be worth to present more details about the cases, that would give a wider picture to the reader. The authors have also been successful in this part. They managed in approachable way extremely complicated and multifaceted topics.

The reviewed monograph is an original and creative contribution to the development of study about American law, which also gives a different view on some topics related to European systems. It presents comprehensive considerations on the most important act of law in America. Readers have the opportunity to supplement and enrich their knowledge, both historical and related to current matters. Konstytucja USA. Ze studiów nad amerykańskim systemem politycznym (The United States Constitution. From the Studies of the American Political System) is an interesting 
Pobrane z czasopisma Studia Iuridica Lublinensia http://studiaiuridica.umes.pl Data: 26/04/2023 10:57:13

collection of works, very carefully selected to create a coherent set. The articles were written by mostly young and inexperienced researchers, who uses different methods and approaches to make their articles more understandable and distinctive. It is obvious that in each of the individual articles we can find imperfections, but it must be noted how accurately and earnestly they were written. Sometimes there are no details or more accentuated conclusions, but from the perspective of the whole, this work should be assessed as very successful. 